\title{
Effects Of Advertising Campaigns On Marketing Performance (A Study Of Nigerian Bottling Company Plc, Enugu)
}

\author{
Luke Raymond Godday \\ Department Of Marketing, Niger Delta University, \\ Wilberforce Island, Bayelsa State.
}

\begin{abstract}
This study sought to evaluate the Effects of Advertising Campaigns on Marketing Performance, Nigerian Bottling Company Pic, Enugu. The general objective of this study was: to examine the effects of advertising campaign on marketing performance. The study employed descriptive research design using survey method. Data was collected through the primary and secondary source, while primary source data were from field survey which is questionnaire, the secondary were from already existing literatures like books and journals. The population here was made of Nigerian Bottling Company customers and consumers, the population was non-finite, as such, Fred and Williams formula was used, after pilot's survey, to find the sample size of 323. The reliability of this study was determined with test and retest method at the value of 0.83 . Data were collated on tables and graphs. Chi-square was used in the test of hypotheses and Statistical Package for Social Sciences (SPSS) was used in the computation. The findings of the study revealed that advertising campaigns had significant effects on organizational performance, advertising media channels had significant influence on brand loyalty, advertising budgets had significant influence as an organization or company, one needs to pay recommends that in order to have a great performance as an organization or company, one needs to pay proper attention on advertising, if enough advertising is not done in an organization, the performance of that organization would be poor. Organizations should know that it is very necessary to evaluate an advertising campaign at the end of every advertising campaign. Organizations should know that an effective advert campaign evaluation is not only on the increase of sales but also on the awareness created and the relationship that has been established with the consumers for repeat purchase.
\end{abstract}

Keywords: Advertising, campaign, marketing, performance

\section{INTRODUCTION}

The primary mission of any advertisement is to reach its prospective customers and influence their awareness attitude and buying behaviour. This buying behaviour is whatever the customer does in the process of satisfying his or her needs or wants. This behaviour comprises of both types: overt behaviour and covert behaviour. Advertising should be done in a positive way to influence buyers and increase sales, and to succeed in whatever they do. Advertising is any paid form of non-personal presentation and promotion of ideas, goods, or services by an identified sponsor (Mesharch, 2007).

Advertising is used to inform, educate, persuade and remind active and potential consumers of the existence of the company's products. Advertising objectives is the specific communication task to be accomplished with a specific target audience during a specific period of time. Advertising is different from every other promotional tool, as it is a non-personal and mass media oriented to reach its target audience. It is made up of three parties: the sponsor, the media, and the advert agent. Advertising campaign comprises of five M's which are basically the important decisions that are to be taken when designing the advertisement campaign. They 
are: Mission, Money, Message, Media and Measurement. When deciding on the advertising decision four important decisions must be taken in developing advertising campaign: setting advertising objectives, setting advertising budget, developing advertising strategy and evaluating advertising campaigns.

Advertising campaign planning and execution or implementation helps the advertising practitioner, not to see each activity in advertising as standing apart but as part of one big effort. It ties together and presents a united picture of the entire advertising process (Abiodum 2011). It lasts for a period of six months or so and involves series of advertising and other activities to qualify as advertising campaign (Kazimi, 2005).

Advertising campaign also is an organized series of advertising messages with identical or similar messages over a particular period of time. It is an orderly self-contained and independent advertisement though the campaign is conveyed through different media's it has a single theme and unified approach.

Advertising campaigns appear in different media channels across a specific time frame that often needs to be defined clearly. It is also seen as series of advert messages that share a single idea and theme which makes up an integrated marketing communication. Integrated marketing communication is made up of varieties of marketing communication tools: advertising, direct response, sales promotions and public relations. Companies who use this concept, works out a role that the various tools play and the extent to which each would be used (Kotler 2009).

Modern advertising campaigns often combine multiple online and offline advertising channels. In online we have: social-media, email marketing, website or blog promotion. While in offline channel we have: newspapers, magazine, television and radio. Online and offline marketing are usually used to generate attention and enthusiasm for subject of the campaign, often with the logical and timely launch of different tools at specific point in the overall campaign. Advertising campaign is intentionally and carefully coordinates series of marketing tools in order to reach the target audience.

The critical part of making an advertising campaign is to determine a campaign theme as it sets the tone for individual advertisement and other forms of marketing communication that will be used. Advertising campaigns are developed to achieve a particular goal or set of goals, such goals typically includes: establishing a brand, raising brand awareness, increasing the rates or volumes of sales. The degree of success or failure in reaching these goals, are measured with some analytical tools and they are five in number, namely: integrated marketing communication, media channel, positioning, communication process and touch points.

Advertising campaign is of three types: the word hook, the character hook, the repeatable hook and consistent layout. There are also points to be considered while planning an advertising campaign: identify the problem, budget, pre testing, target audience, media selection, the language, visual timing and duration, post testing and effect on sales.

Organizational performance is the final achievement of an organization which is measured either in financial and lion-financial indicators, and contains a few things, such as the existence of certain targets are achieved, has a period of time in achieving the targets and the realization of efficiency and effectiveness (Kotler, 2013). On the other hand, organizational performance refers to ability of an enterprise to achieve such objectives as high profit, quality product, large market share, good financial results, and survival at pre-determined time using relevant 
strategy for action (Donald, 2002). Organizational performance can also be used to view how and enterprise is doing in terms of level of profit, market share and product quality in relation to other enterprises in the same industry. Consequence, it is a reflection of productivity of members of an enterprise measured in terms of revenue, profit, growth, development and expansion of the organization.

All types of organization, whether small or big, public private, for-profit or non-profit, struggle for survival. In order to survive, they need to be successfully (effective and efficient). To assure their success, organizations must perform well. Ultimately, performance lies at the heart of any managerial process and organizational construct and is therefore considered as a critical concept in the strategic management field. Organizational performance includes multiple activities that help in establishing the goals of the organization, and monitor the progress towards the target (Haruna, 2005).

The subject matter of this project research project work is to study the effects of advertising campaign on marketing performance, Nigerian Bottling Company Enugu. This research is of great importance to various enterprises and organizations wishing to conduct a detailed study of advertising campaign.

\section{Statement of the Problem}

It is an established fact that advertising plays a very significant role in creating product or service awareness in the market place. David and James (1982) argued that advertising is one easy way to educate existing and prospective consumers about a product or service. Although it is common for people to relate the performance of a company budgets are a huge source of costs for the organization. In fact, the amount of resources committed by firms to advertising has steadily grown over the years because of the increased awareness and sophistication of consumers (Kotler, 2009).

Nigerian Bottling Company carries out frequent advertising of their products to increase their performance volume or patronage through taking part in charitable funds in Nigeria and even sponsoring sports. It advertises using radio, television, newspaper and even social media.

The vast growth in the economy has made it possible for customers and consumers to seek for the best satisfaction of their needs and wants. However, producers have also seen a need to upgrade their product since they now that it will not cost them to attract new customers but to retain new and existing ones (Kotler and Keller, 2013).

The rate of patronage of these soft drinks in Nigerian Bottling Company Enugu, decreased as a result of substitute product: 7up Bottling Company, the competition in the market is tight. Despite its success in advertising regularly, Nigerian Bottling Company still need to go through the use of advertising campaign in maintaining its customer loyalty and influence the buying behaviour of its consumer, who would have easily gone for a substitute product 7up Bottling Company: 7up, Pepsi, Mirinda, and so on.

This study wishes to evaluate the effectiveness or effects of advertising campaign on marketing performance.

\section{Objective of the Study}

The general objective of this study was to assess the significant effects of advertising campaign on marketing performance. 
The specific objectives of the study were;

1. To determine the extent to which the advertising media channels affect brand awareness in Nigerian Bottling Company Pic Enugu.

2. To assess the significant influence of advertising message generalization on the consumers' patronage of Nigerian Bottling Company Pic Enugu.

3. To evaluate the significant influence of advertising budgets on the brand's penetration of Nigerian Bottling Company Pic Enugu.

4. What is the significant influence of advertising measurement on the brand loyalty to Nigerian Bottling Company Pic, Enugu?

\section{Research Questions}

1. What is the significant effect of advertising campaign on marketing performance?

2. Does advertising media channels have significant effects on the brand awareness of Nigerian Bottling Company Pic Enugu?

3. What is the significant influence of advertising message generalization on the consumers' patronage of Nigerian Bottling Company Pic, Enugu?

4. How does advertising budgets have significant influence on the brand's penetration of Nigerian Bottling Company Pic, Enugu?

5. What is the significant influence of advertising measurement on the brand loyalty to Nigerian Bottling Company?

\section{Research Hypotheses}

i. Ho: Advertising campaigns do not have significant effects on marketing performance,

ii. Ho: Advertising media channels do not have significant influence on the brand awareness in Nigerian Bottling Company Pic Enugu.

Ha: Advertising media channels have significant influence on the brand awareness in Nigerian Bottling Company Pic Enugu.

iii. Ho: Advertising message generalization do not have significant influence on the consumer's patronage of Nigerian Bottling Company Enugu Pic.

Ha: Advertising message generalization has significant influence on the consumers' patronage of Nigerian Bottling Company Enugu Pic.

iv. Ho: Advertising budgets do not have significant influence on the brand's penetration of Nigerian Bottling Company Enugu Pic.

Ha: Advertising budgets have significant influence on the brand's penetration of Nigerian Bottling Company Enugu Pic.

v. Ho: Advertising measurement does not have significant influence on the brand loyalty to Nigerian Bottling Company Pic, Enugu.

Ha: Advertising measurement has significant influence on brand loyalty to Nigerian Bottling Company Pic, Enugu.

\section{Significance of the Study}

The study expects to yield a number of desirable benefits, the most essential of which is contribution to existing knowledge. Specifically, the findings of the study will provide direction as to the effect of awareness on the increase of demand and profit of manufacturing companies. Similarly, the study also hopes to expand the frontiers of knowledge, the area of conducting its analysis through the use of techniques that have been overlooked by previous researchers on the effect of advertising campaign on the performance of companies or organizations in Nigeria.

The importance of the findings of the study to the managers of manufacturing firms in Nigeria, could not be quantified in that it would provide evidence with respect to the justification of 
managers' increased resource commitment to advertising in Nigeria. The findings would equip managers with better insights on how to juxtapose the benefits of increase in advertising performance and sales.

This study will help firms understand the importance of advertising campaign, enable them structure their adverts and make them more appealing in order to improve sales which leads to a better performance. This study also gives a clear insight on how advertisement can influence consumer behaviour. Firms will be encouraged into using adverts to market their products, when the firms start making more income tax will be accrued to the Government.

The findings of this study will go a long way in helping firms to adopt good advertising strategies and appealing brand designs to help get more customers for their products and services. This study is important for institutions, who wish to know more about advertising campaign. It is also important to researchers in the field of advertising. It will serve as a source of secondary data.

\section{Research Design}

\section{METHOD AND MATERIALS}

The researcher used descriptive research design. The researcher carried out a descriptive survey of opinion of respondents on the effects of advertising campaign on marketing performance on Nigerian Bottling Company Enugu 9th mile.

Research design provides the conceptual framework within which research is conducted; it constituted the blueprint or roadmap for the collection, measurement and analysis of data (Kothari, 2007). Research design is the specification of procedures for collection, and analyzing the data necessary to help solve the problem at hand, such that the difference between the cost of obtaining various levels of accuracy and the expected value of information associated with each level of accuracy is maximized, (Bello, 2011). The research design adopted was cross sectional descriptive design. According to Cooper and Schindler (2000), a descriptive research design is concerned with finding out the, who, what, where, when and how much. Furthermore, a research design is structured, has investigative questions and part of formal studies.

\section{Area of Study}

The area of study of this research was basically Coca-Cola Bottling Company 9th mile Enugu State, Nigeria. Enugu is a state in the South-Eastern Nigeria, its capital is Enugu, which was created from the old Anambra 1991. The state shares borders with Abia state, Imo state, to the south Ebonyi state, to the east Benue state, to the northeast Kogi state, to the northwest and Anambra. It latitude 60 30" East, the state has a total of area of 7, 161 square kilometer with the population of 3.3 million in 2012.

\section{Sources of Data}

Data were collected through primary source. Data were collected directly by means of questionnaires which were distributed to the target sample. The questionnaire contained twelve (12) items and they were distributed to customers of Nigeria Bottling Company consumers and customers Enugu 9th mile.

Data in research are raw facts collected from the field or from existing literature, meant to be processed and interpreted into relevant information (Agha, 2011). And data were collected through the secondary source, through text books, lecture note, journals and internet. 


\section{Population of the Study}

The population of the study was Non-finite as it comprises of all consumers and the customers of and around Nigerian Bottling Company Enugu 9th mile.

Population refers to an entire group of individuals, event or objects having common characteristics that can be observed and measured (Mark and Adrwin, 2009).

\section{Sample Size Determination}

The sample size comprises of customers and consumers of Nigeria Bottling Company Enugu 9th mile. But after a pilot survey of the customers and consumers of Nigerian Bottling Company Enugu 9th mile, the researcher asked about the total of 100 persons on the performance and patronage. Only 70 responded positively.

Therefore, the researcher would used a non-finite population formula by Fred Williams to determine the sample size.

Where $\mathrm{Z}=$ Critical Value -1.96

$$
\frac{n=Z^{2} P Q}{e^{2}}
$$

$\mathrm{P}=$ Probability of success

$\mathrm{Q}=$ Probability of failure

Note, $P+Q=1$

Total No. of people asked $=100$

No. of yes is $\frac{70=70}{100}=0.7$

No. of yes is $\frac{30=30}{100}=0.3$

Therefore, $\frac{\mathrm{N}=Z^{2} P Q}{e^{2}(0.05)^{2}}=\frac{(1.96)^{2} \times 0.7 \times 0.3}{0.00250 .0025}=3.8416 \times 0.7 \times 0.3=0.806736$

$=322.6944$

$\mathrm{N}=323$

\section{Sampling Techniques}

Here, the researcher used a non-probability purposive sampling technique. To look at the selected target from all available angles. The researcher chose some customers and consumers with the purpose of getting the appropriate answer when the questionnaire was shared, about the performance of Nigerian Bottling Company Pic 9th mile Enugu. The researcher met some customers at shops, restaurants, fast foods, shopping malls, with consumers, consuming some of their products and shared the questionnaire, while the researcher shared to some who were purchasing their products.

\section{Method of Data Collection}

The researcher used primary source, data were collected directly by means of questionnaires which were distributed to the purposive customers who consume and purchase the products, at their convenience time in order to get their right responses so the researcher could get the right level of the company's performance. Primary data was collected through selfadministered questionnaires containing closed questions. A questionnaire, as the data collection instrument of choice is, easy to formulate and administer and also provides a relatively simple and straightforward approach to the study of attitudes, values. Beliefs and motive (Robson, 2002). Questionnaires was also being adapted to collect generalized information from almost any human population and results to high amounts of data 
standardization. The questionnaires were distributed through the sharing method. There was a follow- up to ensure that questionnaires are collected on time and assistance to the respondents having difficulty in completing the questionnaires was offered. This ensured that the information gathered was valid, reliable and suitable for this study.

\section{Validity of Research Instrument}

This work was validated by two experts in the area of research.

Validity in research refers to the extents to which the researcher weights and certifies what the researcher intend to measure (Agha 2011).

Validity of measuring instrument refers to the degree to which an instrument measures what it is supposed to measure, the researcher used a face validity approach.

\section{Reliability of Research Instrument}

The reliability test adopted in this research work is Test-Retest reliability; which refers to administering the same test instrument to the same targeted group, representing about $10 \%$ of the sample size on two occasions and correlated the paired shares (Agha, 2011). The test and retest method of reliability and the coefficient of the mean variable of the test and retest was 0.83. This indicated that the study instruments were reliable.

Reliability is the degree of consistency through which a measuring instrument measures whatever it is measuring. Reliability is the accuracy and precision of the result gotten over time.

\section{Data Presentation and Analyses}

Data were collect through descriptive design using survey method, which were further analyzed using statistical formulae like percentage, tables, bar charts chi-square simple text and statistical package for social science (SPSS). The chi-square (x2) is a very popular form of hypothesis testing where the data collected is not from a random sample. It is sum of ratios of differences between observed and expected.

Where:

$$
\text { Chi square }(\mathrm{x} 2)=\Sigma \frac{(\mathrm{Fo}-\mathrm{Fe})^{2}}{\mathrm{Fe}}
$$

$\Sigma=$ Summations of frequencies

$\mathrm{f}=$ Observed frequencies

$\mathrm{e}=$ expected frequencies

$\mathrm{x} 2=$ the sum of the quantities which we obtained by dividing the squared differences. Expected frequency (e) is the mean of the observed frequency. It enables one to know how much deviation is based on mean. 
Respondents Consumers and Customers' Cross Tabulation

\begin{tabular}{|c|c|c|c|c|c|c|}
\hline \multirow[t]{2}{*}{ Respondents } & \multicolumn{5}{|c|}{ Responses } & \multirow[t]{2}{*}{ Total } \\
\hline & 1.00 & 2.00 & 3.00 & 4.00 & 5.00 & \\
\hline Count & 14 & 20 & 14 & 40 & 60 & 148 \\
\hline Customers Expected Count 1\% within & 12.6 & 18.4 & 25.2 & 34.4 & 57.4 & 148.0 \\
\hline $\begin{array}{l}00 \text { customers } \\
\% \text { within }\end{array}$ & $9.5 \%$ & $13.5 \%$ & $9.5 \%$ & $27.0 \%$ & $40.5 \%$ & $100.0 \%$ \\
\hline $\begin{array}{l}\text { Consumers } \\
\% \text { of Total }\end{array}$ & $63.5 \%$ & $62.5 \%$ & $31.8 \%$ & $66.7 \%$ & $60.0 \%$ & $57.4 \%$ \\
\hline Count & $5.4 \%$ & $7.8 \%$ & $5.4 \%$ & $15.5 \%$ & $23.3 \%$ & $57.4 \%$ \\
\hline $\begin{array}{l}\text { Expected } \\
\text { Count }\end{array}$ & 8 & 12 & 30 & 20 & 40 & 110 \\
\hline $\begin{array}{l}2 \% \text { within } \\
00 \text { Customers }\end{array}$ & 9.4 & 13.6 & 18.8 & 25.6 & 42.6 & 110.00 \\
\hline $\begin{array}{l}\text { Consumes \% within } \\
\text { Consumers }\end{array}$ & $7.3 \%$ & $10.9 \%$ & $27.3 \%$ & $18.2 \%$ & $36.4 \%$ & $100.0 \%$ \\
\hline $\begin{array}{l}\% \text { of Total } \\
\text { Count }\end{array}$ & $36.4 \%$ & $37.5 \%$ & $68.2 \%$ & $33.3 \%$ & $40.0 \%$ & $42.6 \%$ \\
\hline Expected & $3.1 \%$ & $4.7 \%$ & $11.6 \%$ & $1.8 \%$ & $15.5 \%$ & $42.6 \%$ \\
\hline $\begin{array}{l}\text { Count } \\
\% \text { within }\end{array}$ & 22 & 32 & 44 & 60 & 100 & 258 \\
\hline Total Consumers & 22.0 & 32.0 & 44.0 & 60.0 & 100.0 & 258.0 \\
\hline & $8.5 \%$ & $12.4 \%$ & $17.1 \%$ & $23.3 \%$ & $38.8 \%$ & $100.0 \%$ \\
\hline & $8.5 \%$ & $12.4 \%$ & $17.1 \%$ & $23.3 \%$ & $38.8 \%$ & $100.0 \%$ \\
\hline
\end{tabular}

Case Processing Summary

\begin{tabular}{|l|c|c|c|c|c|c|}
\hline \multirow{2}{*}{ Respondents } & \multicolumn{6}{|l|}{ Cases } \\
\cline { 2 - 7 } & Valid & Missing & N & Percent & N & Percent \\
\hline $\begin{array}{l}\text { Customers } \\
\text { Consumers }\end{array}$ & 258 & $98.5 \%$ & 4 & $1.5 \%$ & 262 & $100.0 \%$ \\
\hline
\end{tabular}

Chi-Square Tests

\begin{tabular}{|l|c|c|c|}
\hline & Value & Df & $\begin{array}{c}\text { Asymp. Sig. } \\
\text { (2-sided) }\end{array}$ \\
\hline Pearson Chi-Square & $14.846^{\mathrm{a}}$ & 4 & .005 \\
Likelihood Ratio & 14.838 & 4 & .005 \\
Linear-by-Linear & .378 & 1 & .539 \\
Association & 258 & & \\
N of Valid Cases & & & \\
\hline
\end{tabular}

A. 0 cell $(0.0 \%)$ have expected count less than 5

The minimum expected count is 9.38 .

Ho: Advertising media channels do not have significant influence on the brand awareness in Nigerian Bottling Company Plc Enugu.

Ha: Advertising media channels have significant influence on the brand awareness in Nigerian Bottling Company Plc Enugu. 
Respondents Consumers and Customers' Cross Tabulation

\begin{tabular}{|c|c|c|c|c|c|c|}
\hline \multirow{2}{*}{ Respondents } & \multicolumn{5}{|c|}{ Responses } & \multirow[t]{2}{*}{ Total } \\
\hline & 1.00 & 2.00 & 3.00 & 4.00 & 5.00 & \\
\hline Count & 12 & 18 & 10 & 30 & 60 & 130 \\
\hline $\begin{array}{l}\text { Customers Expected Count } \\
10 \% \text { within }\end{array}$ & 11.1 & 18.1 & 10.1 & 25.2 & 65.5 & 130.0 \\
\hline $\begin{array}{l}0 \text { customers } \\
\% \text { within }\end{array}$ & $9.2 \%$ & $13.8 \%$ & $7.7 \%$ & $23.1 \%$ & $46.2 \%$ & $100.0 \%$ \\
\hline $\begin{array}{l}\text { Consumers } \\
\% \text { of Total }\end{array}$ & $54.5 \%$ & $50.0 \%$ & $50.0 \%$ & $60.0 \%$ & $46.2 \%$ & $50.4 \%$ \\
\hline Count & $4.7 \%$ & $7.0 \%$ & $3.9 \%$ & $11.6 \%$ & $23.3 \%$ & $50.4 \%$ \\
\hline $\begin{array}{l}\text { Expected } \\
\text { Count }\end{array}$ & 10 & 18 & 10 & 20 & 70 & 128 \\
\hline $\begin{array}{l}2.0 \% \text { within } \\
0 \text { Customers }\end{array}$ & 10.9 & 17.9 & 9.9 & 24.8 & 64.5 & 128.0 \\
\hline $\begin{array}{l}\text { Consumes \% within } \\
\text { Consumers }\end{array}$ & $7.8 \%$ & $14.1 \%$ & $7.8 \%$ & $15.62 \%$ & $54.7 \%$ & $100.0 \%$ \\
\hline $\begin{array}{l}\% \text { of Total } \\
\text { Count }\end{array}$ & $45.5 \%$ & $50.0 \%$ & $50.0 \%$ & $40.0 \%$ & $53.8 \%$ & $49.6 \%$ \\
\hline Expected & $3.9 \%$ & $7.0 \%$ & $3.9 \%$ & $7.8 \%$ & $27.1 \%$ & $49.6 \%$ \\
\hline $\begin{array}{l}\text { Count } \\
\% \text { within }\end{array}$ & 22 & 36 & 20 & 50 & 130 & 258 \\
\hline Total Consumers & 22.0 & 36.0 & 20.0 & 50.0 & 130.0 & 258.0 \\
\hline & $\begin{array}{c}8.5 \% \\
\% \\
8.5 \%\end{array}$ & $\begin{array}{c}14.0 \% \\
\% \\
14.0 \%\end{array}$ & $\begin{array}{c}7.8 \% \\
\% \\
7.8 \%\end{array}$ & $\begin{array}{c}19.4 \% \\
\% \\
19.4 \%\end{array}$ & $\begin{array}{c}50.4 \% \\
\% \\
50.4 \%\end{array}$ & $\begin{array}{c}100.0 \% \\
\% \\
100.0 \%\end{array}$ \\
\hline
\end{tabular}

Case Processing Summary

\begin{tabular}{|l|c|c|c|c|c|c|}
\hline \multirow{2}{*}{ Respondents } & \multicolumn{6}{|l|}{ Cases } \\
\cline { 2 - 7 } & Valid & Missing & N & Percent & N & Percent \\
\hline $\begin{array}{l}\text { Customers } \\
\text { Consumers }\end{array}$ & 258 & $98.5 \%$ & 4 & $1.5 \%$ & 262 & $100.0 \%$ \\
\hline
\end{tabular}

Chi-Square Tests

\begin{tabular}{|l|c|c|c|}
\hline & Value & Df & $\begin{array}{c}\text { Asymp. Sig. } \\
\text { (2-sided) }\end{array}$ \\
\hline Pearson Chi-Square & $12.936^{\mathrm{a}}$ & 4 & .569 \\
Likelihood Ratio & 2.950 & 4 & .566 \\
Linear-by-Linear & & & \\
Association & .508 & 1 & .476 \\
N of Valid Cases & 258 & & .539 \\
\hline
\end{tabular}

a. 0 cell $(0.0 \%)$ have expected count less than 5

\section{Test of Hypotheses 3}

Ho: Advertising measurement does not have significant influence on brand loyalty to Nigerian Bottling Company Plc, Enugu.

Ha: Advertising measurement has significant influence on brand loyalty Nigerian Bottling Company Plc, Enugu. 
Respondents Consumers and Customers' Cross Tabulation

\begin{tabular}{|c|c|c|c|c|c|c|}
\hline \multirow[t]{2}{*}{ Respondents } & \multicolumn{5}{|c|}{ Responses } & \multirow[t]{2}{*}{ Total } \\
\hline & 1.00 & 2.00 & 3.00 & 4.00 & 5.00 & \\
\hline Count & 14 & 14 & 10 & 230 & 50 & 108 \\
\hline $\begin{array}{l}\text { Customers Expected Count } \\
10 \% \text { within }\end{array}$ & 10.0 & 14.2 & 8.4 & 20.9 & 54.4 & 108.0 \\
\hline $\begin{array}{l}0 \text { customers } \\
\% \text { within }\end{array}$ & $13.0 \%$ & $13.0 \%$ & $9.3 \%$ & $18.5 \%$ & $46.3 \%$ & $100.0 \%$ \\
\hline $\begin{array}{l}\text { Consumers } \\
\% \text { of Total }\end{array}$ & $58.3 \%$ & $41.2 \%$ & $50.0 \%$ & $40.0 \%$ & $38.5 \%$ & $41.9 \%$ \\
\hline Count & $5.4 \%$ & $5.4 \%$ & $3.9 \%$ & $7.8 \%$ & $19.4 \%$ & $41.9 \%$ \\
\hline $\begin{array}{l}\text { Expected } \\
\text { Count }\end{array}$ & 10 & 20 & 10 & 30 & 80 & 150 \\
\hline $\begin{array}{l}2.0 \% \text { within } \\
0 \text { Customers }\end{array}$ & 14.0 & 19.8 & 11.6 & 29.1 & 75.6 & 150.0 \\
\hline $\begin{array}{l}\text { Consumes \% within } \\
\text { Consumers }\end{array}$ & $6.7 \%$ & $13.3 \%$ & $6.7 \%$ & $20.0 \%$ & $53.3 \%$ & $100.0 \%$ \\
\hline $\begin{array}{l}\% \text { of Total } \\
\text { Count }\end{array}$ & $41.7 \%$ & $58.8 \%$ & $50.0 \%$ & $60.0 \%$ & $61.5 \%$ & $58.1 \%$ \\
\hline Expected & $3.9 \%$ & $7.8 \%$ & $3.9 \%$ & $11.6 \%$ & $31.0 \%$ & $58.1 \%$ \\
\hline $\begin{array}{l}\text { Count } \\
\text { \% within }\end{array}$ & 24 & 34 & 20 & 50 & 130 & 258 \\
\hline $\begin{array}{l}\text { Consumers } \\
\text { Total \% within } \\
\text { Consumers }\end{array}$ & 24.0 & 34.0 & 20.0 & 50.0 & 130.0 & 258.0 \\
\hline$\%$ of Total & $9.3 \%$ & $13.2 \%$ & $7.8 \%$ & $19.4 \%$ & $50.4 \%$ & $100.0 \%$ \\
\hline & $\begin{array}{c}100.0 \\
\% \\
9.3 \%\end{array}$ & $\begin{array}{c}100.0 \\
\% \\
13.2 \%\end{array}$ & $\begin{array}{c}100.0 \\
\% \\
7.8 \% \\
\end{array}$ & $\begin{array}{c}100.0 \\
\% \\
19.4 \% \\
\end{array}$ & $\begin{array}{c}100.0 \\
\% \\
50.4 \% \\
\end{array}$ & $\begin{array}{c}100.0 \\
\% \\
100.0 \%\end{array}$ \\
\hline
\end{tabular}

Case Processing Summary

\begin{tabular}{|l|c|c|c|c|c|c|}
\hline \multirow{2}{*}{ Respondents } & \multicolumn{4}{|l|}{ Cases } \\
\cline { 2 - 7 } & Valid & Missing & N & Percent & N & Percent \\
\hline $\begin{array}{l}\text { Customers } \\
\text { Consumers }\end{array}$ & 258 & $98.5 \%$ & 4 & $1.5 \%$ & 262 & $100.0 \%$ \\
\hline
\end{tabular}

Chi-Square Tests

\begin{tabular}{|l|c|c|c|}
\hline & Value & Df & $\begin{array}{c}\text { Asymp. Sig. } \\
\text { (2-sided) }\end{array}$ \\
\hline Pearson Chi-Square & $13.915^{\mathrm{a}}$ & 4 & .418 \\
Likelihood Ratio & 3.866 & 4 & .424 \\
Linear-by-Linear & & & \\
Association & 2.498 & 1 & .114 \\
N of Valid Cases & 258 & &. \\
\hline
\end{tabular}

a. 0 cells $(0.0 \%)$ have expected count less than 5

The minimum expected count is 8.37

\section{DISCUSSION OF RESULTS}

The analysis of hypothesis one showed that advertising campaigns have significant effects on marketing performance. Decision was taken because the Null hypothesis was rejected, since the calculated value of 14.846 was greater than the critical value 9.488 , which was determined at $5 \%$ level of significance degrees of freedom. Meanwhile, this result is in agreement with the findings made in a related study carried out by Jannet Jebungei, influence of Advertising on 
marketing, (organizational) performance, which it was discovered that advertising has a significant effect on organizational performance. Kamber, (2002) who noted that advertising campaigns were successful in increasing sales for products with unique attributes, were geared to the consumer market and backed by adequate financial resources, and when they featured unique and creative massages. It also found that advertising results in profit maximization and purchase of organizational products by the consumers.

In the analysis of hypothesis two, advertising media channels have significant influence on the brand awareness in Nigerian Bottling Company Pic Enugu. This was so because the Null hypothesis was rejected, since the calculated value of 12.936 was greater than the critical value 9.488, which was determined at $5 \%$ level of significance and four degrees of freedom. However, the result is similar in a related study carried out by Saandage and Peagan et al (2002) findings that the role of advertisement in an organization is to make known the availability of a product or service to sell. Morden (1991) is of the opinion that advertising is used to establish a basic awareness of the product or service in the mind of the potential customer and to build up knowledge about it while at the same time creating employment.

Finally, the analysis of hypothesis three showed that advertising measurement has significant influence on brand loyalty to Nigerian Bottling Company, Pic, Enugu. This decision was taken because the Null hypothesis was rejected, since the calculated value of 13.915 was greater than the critical value 9. 488, which was determined at $5 \%$ level of significance and four degrees of freedom. Advertising campaign is working, when advertising effectiveness is generally deemed to have proved when shifts in attitude or increase in sales and awareness Robert (2002) Evaluation and measurement is an essential step to advertising strategy, without evaluation you can't identify your achieved objectives same with measurement, the company needs to measure their advertising strategy to know if they got some returns or not.

According to Ferguson (1974). "Advertising increase barriers to entry and reduce competition as measured by increase in monopoly profit". Moreover, according to Nickels et al (1999) advertising not only helps to maintain superior stand in the industry and profit maximization, it provides information about a products or services and also gives consumer free television and radio programmes. Giles (1997) sees advertising as non-personal communication directed at a target audience through various media in order to present and promote products, services and ideas. The cost of media space, time and advertisement production is borne by the sponsor or sponsors. Advertising gives a clear image for any product or service of a company which is a great asset. A well-structured and continuous advertising might stand as one of those strategies to sustain a distinct marled position. It could also help to identify strong market competitors.

\section{CONCLUSION}

From the study it can be concluded that advertising campaign plays a major role in the performance of an organization as it creates awareness while at the same time encouraging the nonusers to try the products or services of the firm and this will make the company to be competitive. Advertising not only helps the companies to maintain superior stand in the industry and profit the main purpose of this study research work is to determine the effects of advertising campaigns on the performance of an organization. The result found that the advertising campaign has an effect on the performance of an organization as the use of media channels are used to create brand awareness of the company's product, it also found that advertising measurement influences brand loyalty. 
The results of this study were similar to the previous related studies about the effects of advertising campaigns on the performance of an organization. Sandage and Rotzoll (2001) Mordem (1991 Robert 2002 Ferguson (1974). "Nickels e al (1999) Giles (1997).

When the advert is evaluated companies should not only check increase in sales but should also check how many new customers they have been able to obtain and keep them loyal. Okpara, (2002) Evaluation and measurement is an essential step to advertising strategy, without evaluation you can't identify your achieved objectives, same with measurement, the company needs to measure their advertising strategy to know if they got some returns or not.

\section{RECOMMENDATIONS}

1. In order to have a great performance as an organization or company, one needs to pay proper attention to advertising. If enough advertising is not done in an organization, the performance of that organization would be poor. Organizations should pay more attention to the five m's of advertising decision when preparing an advertising campaign in order to have an effective and efficient advertising campaign.

2. Organizations should know that it is very necessary to evaluate an advertising campaign at the end of every advertising campaign. Organizations should know that an effective advert campaign evaluation is not only on the increase of sales but also on the awareness crated and the relationship that has been established with the consumers repeat purchase. If no adequate measurement is done to evaluate the advertising campaigns, on the level of awareness and sales, it will discourage brand loyalty. Organizations should also be more involved in the continuous evaluation and monitoring of advertising to ensure that goals and objectives set are achieved and appropriate corrective actions are taken in the event of deficiencies. The companies should harmonize all departments so as to realize the goals and objectives of advertising.

3. In order to have a high level of brand awareness you need to know the appropriate media to use when advertising or creating awareness in different locations. Companies should consider several factors before deciding which medium to use to advertise. It is recommended that advert campaigns are relayed from different service providers, the adverts should be used to aid the customers to identify the company's products or service when they are making a purchase decision. If the media channel that is being used is not right, the brand awareness will be low or poor.

4. When planning an advert, you pay more attention to the message you are trying to pass along as it influences consumer's patronage. The message of every advert is very important and determines the level of consumer's patronage. Before an advert campaign is carried, there should be a well-planned budget in order to penetrate the market and have a large market share. Companies should take full advantage of such peak seasons by developing an effective and efficient adverting campaign that can arouse consumer's awareness. Thereby leading to increase in sales.

\section{References}

Abiodun A. O. (2011), The Impact of Advertising on SALES Volume of a product. (A Case Study of Starcomms Pic,) Nigeria: Valkeakoski Degree Programme in International Business Global Market, HAMK University.

Agha, N. (2011). Fundamentals of the Research. Enugu: phyce Kerex Publications.

Ferguson, J. K. (2005). Advertising and competition. Cambridge: Theory Management and fact Cambridge.

Giles, 1997, Successful Marketing Technique Approach, Mac-donald and Evans Ltd.

Haruna, M. (2005). Assessment of the effectiveness of advertising as an element of promotional tools in marketing. (A study of United Nigeria Textiles Ltd). Zaria, Nigeria: Published Masters in Business Administration (MBA),

Ahmadu Bello University, Zaria, Nigeria. 
Kamber, T., (2002), The Brand Managers Dilima: Understanding Advertising Expenditures after Sales Growth during the Recession,' The Journal of Brand Managements, Vol. 1092). Pp. 106-20.

Kazimi, S. H. (2005/ Advertising and sales promotion. U.K: Excel books.

Kotler, P. (2000). Principles of marketing, prentice, New Jersey Hall, Inc.

Kotler, P. (2001). Marketing management. The Millennium Edition, India: Published by Asoke K. Ghosh, PrinticeHall, New Dehhi-Delhi-1100064.

Kotler, P. (2009). Marketing Management. New Jersey: Analysis, planning and control.

Kotler, P. and Keller, K. L. 2005 Marketing Management, Prenctice Hall Private Limited.

Mark, S., Philip, L., and T. (2009). Research Methods for business Students. England: Pearson Education Limited, Edinburgh Gate, Harlow Essex, CM20 2JE.

Meshach, G. G. (2007). "The influence of Radio Advertising on sales volume: An analysis of selected manufacturing firms in Jos'. Journal of management Research and Development. Nasarawa Nigeria: A publication of Department of Business Administration, Nasarawa State University, Keffi Vol. 1 No. 1 June 2007.

Modern, A. R. (2007). Evaluation the effects of advertising and sales promotion campaigns, industrial marketing management. 17 (May), pp. 130.

Nickels W. G Mchugh J.M., McHugh S. M 2000 Understanding Business, U.S.A: International Edition, $5^{\text {th }}$ Edition, McGraw Hill Companies, Inc.

Okpara, G. S. (2002). Contemporary marketing tropical and tropicalized. Enugu: Jacob's classic publisher Ltd.

Peagan, J. et al (2001). The Impact of Promotion/Advertising Expenditures on Citrus Sales. Applied Economics Letters, Vol. 8(10)659-63.

Sandage and Rotzoll (2002). Advertising in contemporary society, Columbus. 